\title{
Dry Gangrene of the Glans Penis Following Surgical Correction of Peyronie's Disease
}

\section{Peyronie Cerrahisi Sonrası Glans Penisin Kuru Gangreni}

\author{
Fatih Akdemir' ${ }^{1}$ Önder Kayıgil2 Emrah Okulu \\ 'Samsun Terme State Hospital, Clinic of Urology, Samsun, Turkiye \\ ${ }^{2}$ Yıldırım Beyazıt University Faculty of Medicine, Department of Urology, Ankara, Turkiye \\ ${ }^{3}$ Ankara Atatürk Training and Research Hospital, Clinic of Urology, Ankara, Turkiye
}

\begin{abstract}
Ischemic gangrene of the glans penis following surgical correction of Peyronie's disease is a very rare condition. Ischemic gangrene is a rare phenomenon due to rich vascular collateral circulation in the penis, but serious complications can occur in patients with vascular insufficiency. There is no standardized method among treatment options. We herein report a patient who was operated due to Peyronie's disease and developed ischemic gangrene of the glans penis in the postoperative period.
\end{abstract}

Keywords: Peyronie's disease, Concorde deformity, Penile disassembly, Venous patch, Ischemic gangrene

$\ddot{0} z$

Peyronie cerrahisi sonrası glans penisin iskemik gangreni çok ender bir durumdur. İskemik gangren, penisin zengin vasküler kollateral dolaşımı sebebiyle nadir görülür. Fakat vasküler yetersizliği olan olgularda ciddi komplikasyonlar ortaya çıkabilir. Standardize edilmiş bir tedavi metodu yoktur. Bu yazıda Peyronie hastalığına bağlı opere edilen ve postoperatif dönemde iskemik glans penis gangreni gelişen olgu sunuldu.

Anahtar Kelimeler: Peyronie hastalığı, Konkord deformitesi, Penil ayrıştırma, Venöz yama, İskemik gangren

\section{Introduction}

Penile necrosis is generally seen in patients with diabetes mellitus and end-stage renal disease, but may also be seen in patients with vascular obstruction, tourniquet syndrome, priapism and venous thrombosis, and in those receiving anticoagulant therapy (1). Additionally, penile prosthesis implantation, circumcision, acute arterial obstruction, Fournier gangrene, spider bite, foreign bodies and trauma are among the other factors that may cause ischemic gangrene (2). Regardless of its etiology, penile necrosis is a very critical condition that may lead to very serious complications, such as loss of penis, and it should be treated urgently. In this report, we present a patient who underwent surgical correction of Peyronie's disease and developed ischemic gangrene of the glans penis in the postoperative period, and a review of the current literature.

\section{Case Report}

A 56-year-old patient presented to our clinic with the complaint of penile curvature. Although the erectile capacity was normal, it was learnt that the patient had difficulty with sexual intercourse for 5 years. In artificial erection provided by a vasoactive material, it was seen that there was concorde deformity and a surgical correction was planned after having spoken with the patient in detail. The patient provided written informed consent. The surgery was started by a cut from the circumcision line, and penile degloving was performed thereafter. A tourniquet was placed at the root of the penis, and an artificial erection was ensured with saline solution. It was observed that the penis had concorde deformity. The penile disassembly technique was used by means of separating the neurovascular bundle, urethra, and glans penis and cavernous tissues from each other (Figure 1a, 1b). Plication was performed

Correspondence: Fatih Akdemir MD, Samsun Terme State Hospital, Clinic of Urology, Samsun, Turkiye

Phone: +90 5384040494 E-mail: nfatihakdemir@hotmail.com ORCID-ID: orcid.org/0000-0003-1794-211X

Received: 26.07 .2017

Accepted: 12.10 .2017

Cite this article as: Akdemir F, Kayıgil Ö, Okulu E. Dry Gangrene of the Glans Penis Following Surgical Correction of Peyronie's Disease. J Urol Surg 2018;5(1):47-50.

${ }^{\circ}$ Copyright 2018 by the Association of Urological Surgery / Journal of Urological Surgery published by Galenos Publishing House. 
to the area of curvature, and saphenous patch was applied by incising and excising the plaques in the lower part and tip of the corpora cavernosa (Figure 2a, 2b). After having corrected the corpora cavernosa, the glans penis was sutured to the corpora cavernosa. A transurethral catheter was placed and a dressing (Coban wrap) was loosely wrapped around the penis. The bandage was removed on postoperative day 1 and the transurethral catheter on day 2. It was seen on postoperative day 5 that necrosis developed on glans penis and the sub-coronal site. In this phase, pentoxifylline ( $3 \times 400 \mathrm{mg} /$ day), acetylsalicylic acid (300 mg/day), tadalafil ( $5 \mathrm{mg} /$ day), enoxaparin ( $60 \mathrm{mg} /$ day), and dipyridamole (2x75 mg/day) were started to prevent glans penis ischemia. On postoperative day 10, necrotic tissues on the glans penis and sub-coronal site were debrided. In the meantime, it was observed that cavernous tissues were separated from the glans penis and there was a clean-cut laceration on the urethra (Figure 3a, 3b, 3c, 3d). A cephalosporin derivative antibiotic was started for prophylaxis for prevention of catheter-associated infection. On postoperative day 15 , the patient was operated on again for debridement, and the glans penis and the cavernous tissues were united. On the $30^{\text {th }}$ day, the glans penis was observed to be epithelized and there was no ischemia (Figure 4a, 4b). Pentoxifylline, tadalafil and dipyridamole were continued for 6 months. Coitus was not recommended for 3 months postoperatively and the patient reported having problem-free sexual intercourse after this period of time.
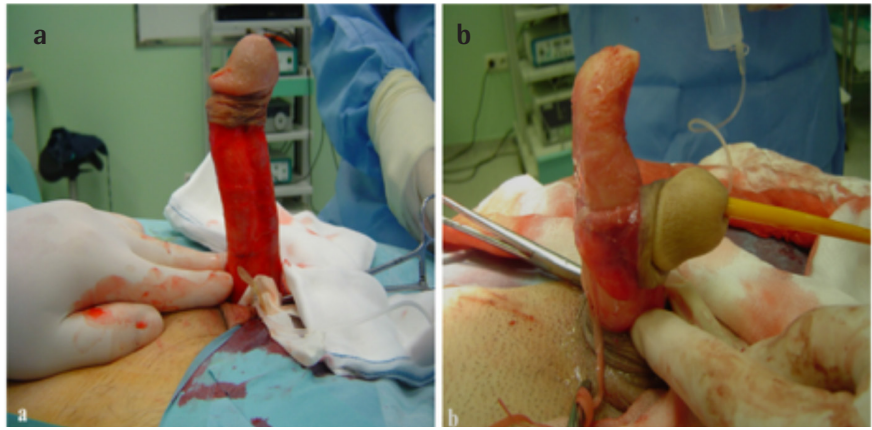

Figure 1. a, b) Concorde deformity of the penis and penile disassembly technique
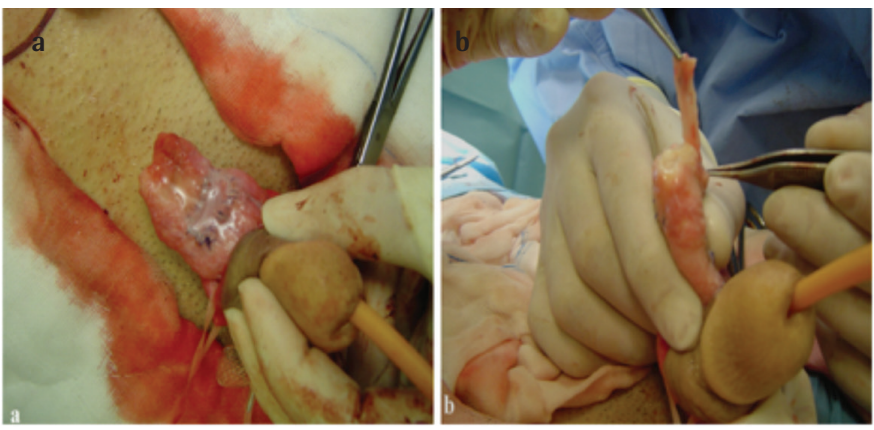

Figure 2. a ,b) Cavernos incision/excision and venous patch

\section{Discussion}

Penile gangrene is an infrequent complication that can occur due to many reasons. Although generally seen in patients with diabetes and end-stage renal disease, other reported causes of penile gangrene involves trauma, vessel narrowing procedures, circumcision, vasculitis (3), acute occlusion of arteries, foreign bodies, Fournier gangrene, spider bites and topical treatment with 1\% gentian violet (2). Also urine extravasation, priapism, narrow bands or pressure from clothing, Wegener's
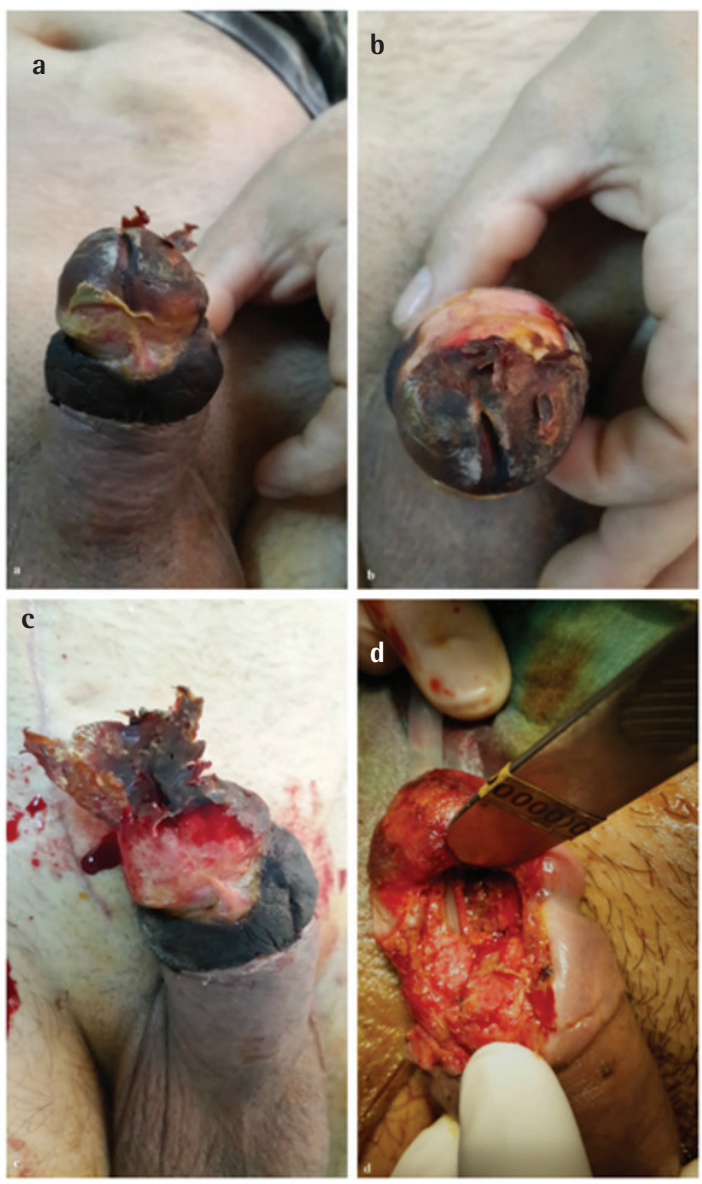

Figure 3. a) Ischemic necrosis of glans penis and sub-coronal area b,c) debridman of the necrotic tissue d) the view of glanulocavernosal dissociation and urethral laceration
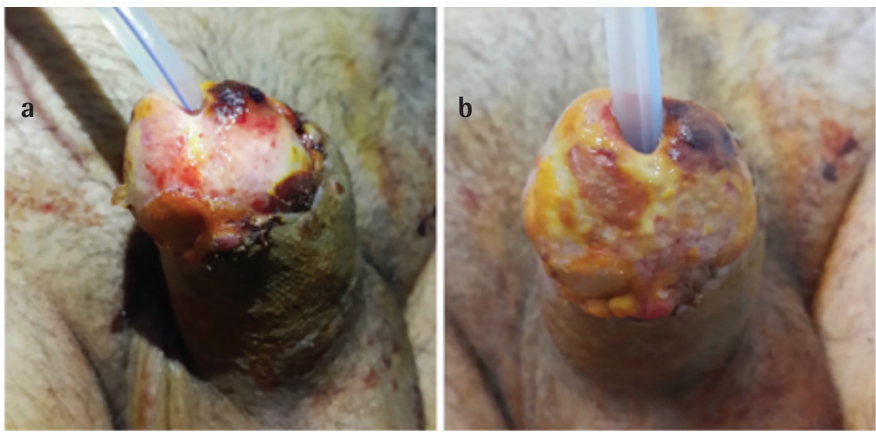

Figure 4. $a, b$ ) The view of re-epithelised glans penis on postoperative day 30 
granulomatosis, septic emboli due to intravenous drug abuse, penile prosthesis implantation and perivascular invasion of penile tumors have been shown to cause penile gangrenes (4).

Inability to remove out metallic and non-metallic objects that are applied to the penis to obtain a longer erection and to increase sexual stimulation and performance after erection can cause complications such as ischemia and dry gangrene besides the mechanical trauma and vascular injury (3). Penile strangulations with use of hair, ring, thread, tape and bottle neck which might be due to mental issues or autoerotic purposes have been reported (5). Ischemia of the glans penis after circumcision generally occurs secondary to the use of the local anesthetic agents during penile block (3). Cases of penile necrosis after a penile prosthesis implantation have been reported. The common feature of these cases was the presence of diabetes. Poor glycaemic control has been reported to play a role in the development of ischemia as well as superinfection (6). A rare medical condition called "calciphylaxis" is characterized by a progressive cutaneous necrosis and ischemia of the lower extremities and penis that occurs as a result of small arterial occlusions at sites of calcification regions. Ohta et al. (7) have reported a case of penile necrosis secondary to calciphylaxis and determined that calciphylaxis associated with long-term diabetes and chronic renal insufficiency were risk factor for penile necrosis.

Although there are various forms of necrosis or gangrene, they are generally divided into two groups as ischemic (dry) or infected (wet). Super-infections can be added upon ischemic necrosis. Thus, in cases of ischemic necrosis, the use of broadspectrum antibiotics is preferred. Wet gangrene developing secondary to infections caused by bacterial agents is more frequently seen in immunocompromised patients, e.g. transplant recipients, human immunodeficiency virus-positive individuals and patients with diabetes mellitus (6).

In our patient, penile plication and venous patch grafting were performed due to Peyronie's disease. The penile disassembly technique was used due to the existing concorde deformity. To the best of our knowledge, the case of glans penis necrosis after implementation of a penile disassembly technique in a patient with Peyronie's disease has not been reported. Although ischemic gangrene causes complications that can even lead to loss of penile tissues, in our patient, we were able to preserve the glans penis after treatments to re-establish micro circulation.

We assume that ischemia of the glans occurring in the postoperative period can be due to the wide dissection of the neurovascular bundle, excision of the plaque in the distal end of the corpus cavernosum and the implementation of a venous patch. A report published by Garcia Gomez et al. (6) is also in line with our view. We also believe that transurethral catheter might have added to the development of the ischemic process.

This is not yet a standardized approach for patients suffering from penile gangrene. In our patient, we started a vasodilator therapy with pentoxifylline ( $3 \times 400 \mathrm{mg} /$ day) and tadalafil (5 mg/day). Also, we used low-molecular-weight heparin (enoxaparin $60 \mathrm{mg} /$ day), acetylsalicylic acid $(300 \mathrm{mg} /$ day) and dipyridamole $(2 \times 75 \mathrm{mg} /$ day) to prevent thrombotic processes. Pentoxifylline is a peripheric vasodilator substance that is reported to be beneficial in preventing ischemic tissue damage. It has been proposed that the preventive effect of pentoxifylline on ischemia-reperfusion injury is mediated via stimulation of prostaglandin synthesis and increase in cyclic 3',5'-adenosine monophosphate after inhibition of the enzyme phosphodiesterase (2). It inhibits the free oxygen radicals as a result of inhibition of xanthine oxydase (8). Aslan et al. (2) has reported a successful treatment of severe glans penis ischemia after circumcision by pentoxifylline treatment.

Dry gangrene of the penis is a rare complication, however, it can result in serious complications. It is important to know the difference between wet and dry gangrenes and to use broadspectrum antibiotics. In cases of wet gangrene, debridement of the infected area should be done and penile amputation may be necessary. Dry gangrene cases can be followed up conservatively if there are no signs of infection. Pentoxifylline can successfully be used in severe ischemia of the glans penis. Also, early diagnosis and treatment is important to improve quality of life, to obtain good cosmetic and functional outcomes and to reduce associated morbidity and mortality.

\section{Ethics}

Informed Consent: The patient signed an informed-consent agreement.

Peer-review: Externally peer-reviewed.

\section{Authorship Contributions}

Surgical and Medical Practices: F.A., Ö.K., Concept: F.A., E.O., Design: F.A., Ö.K., E.O., Data Collection or Processing: F.A., Ö.K., Analysis or Interpretation: F.A., Ö.K., Literature Search: F.A., Ö.K., E.O., Writing: F.A.

Conflict of Interest: No conflict of interest was declared by the authors.

Financial Disclosure: The authors declared that this study received no financial support. 


\section{References}

1. Singh V, Sinha RJ, Sankhwar SN. Penile gangrene: a devastating and lethal entity. Saudi J Kidney Dis Transpl 2011;22:359-361.

2. Aslan A, Karagüzel $G$, Melikoğlu M. Severe ischemia of the glans penis following circumcision: a successful treatment via pentoxifylline. Int J Urol 2005;12:705-707.

3. Burke D, Joypaul V, Thomson MF. Circumcision supplemented by dorsal penile nerve block with $0.75 \%$ ropivacaine: a complication. Reg Anesth Pain Med 2000;25:424-427.

4. Bejany DE, Perito PE, Lustgasten M, Rhamy RK. Gangrene of the penis after implantation of penile ptosthesis: case reports, treatment recommendations and review of the literature. Urol 1993;150:191-192.
5. Malik MH, el Amir Z, Ali M, Ahmed A, Farooqi MA. Penile strangulation: A study of fifteen cases. RMJ. 2012;37:30-33.

6. Garcia Gómez B, Romero Otero J, Díez Sicilia L, Jiménez Alcaide E, GarciaCruz $E$, and Rodriguez Antolin A. Ischemic Gangrene of the Glans following Penile Prosthesis Implantation. Case Rep Urol 2013;2013:323574.

7. Ohta A, Ohomori S, Mizukami T, Obi R, Tanaka Y. Penile Necrosis by Calciphylaxis in a Diabetic Patient with Chronic Renal Failure. Intern Med 2007;46:985-990.

8. Stoop MJ, Dirksen R, Hendriks T. Advanced age alone does not suppress anastomotic healing in intestine. Surgery 1996;119:15-19. 